\title{
THE IMPACT OF OMITTED LESSON PORTIONS ON CONSECUTIVE HIGHER EDUCATION AND NATIONAL DEVELOPMENT
}

\author{
Sutuma Edessa \\ Addis Ababa University, Department of Science and Mathematics Education, \\ College of Education and Behavioral Studies, Ethiopia \\ E-mail: sutuma2002@yahoo.com
}

\begin{abstract}
The study was conducted in 20 selected Secondary Schools to investigate the uncovered omitted portions of the prescribed phase-out and phase-in biology textbooks of grades nine and ten as per the school academic calendar and the curricula. The purpose of the study was to assess the range of completed portions in comparison with the omitted ones and investigate the loss or educational wastages with their continuing impacts on the academic performances of students in the consecutive higher institutions. The strategic tools used for gathering data are classroom observations (lesson plans and delivery interactions) assessments of the covered and the omitted portions of each unit of each grade of the phase-out and phase-in textbooks of biology and exercise books of the students. In view of that, both qualitative and quantitative data were collected; descriptive, evaluative and data analyzing methods were used. The omitted prescribed portions of the phase-out biology of grades nine and ten values accounted for $65.5 \%$ and only $34.5 \%$ of the prescribed portion values were covered. Similarly, the omitted prescribed portions of the phase-in biology of grades nine and ten values accounted for $56 \%$ and only $44 \%$ of the prescribed portion values were covered. The total average of the educational wastage (loss) of both phase-out and phase-in prescribed portion values of biology textbooks accounted for $60.25 \%$ and only $39.75 \%$ of the values were covered. Educational wastages negatively influenced the academic and professional skills of students, affected the quality of higher education by which many students end up with academic dismissals or remain jobless due to incompetency as the record is now and timely increasing. It shows failures in the academic succession of learner in the continuing professional and skill development as well as the determinant of the growth of the country.
\end{abstract}

Key words: Coverage, Educational wastage, Omit, performances, Portion and textbooks 


\section{Introduction}

Education is the most important tool to install basic knowledge and skills towards progress and development in every aspect of social, political and economic life. It is one of the keys to social development and a bridge of changes to the quality of life. Foremost, education is about promoting intellectual curiosity and enquiry that empowers people to solve all kinds of social and environmental problems in both official and hidden curricula. In a globalized world where technology reigns, supreme knowledge is a powerful factor in producing essential materials for the society in the pursuit of economic growth and in enhancing the capacity of individuals to acquire the skills needed to find employment. In a world confronted by many complex challenges like food, peace security and the decline of educational qualities, quality education becomes more and more critical in the development of skills and attitudes in order to analyze societal problems and find solutions.

It is true that education is a fixed asset in one's life from childhood years continuing through Primary, Secondary, Technical Vocational and Educational Training and possibly Tertiary levels and may end once employment begins. Educational policy must arrive at a relevant balanced set of aims and objectives describing what learners should learn and why the development of cognitive, creative and social skills and values are necessary with respect for human rights, the environment, peace and tolerance and cultural diversity to enhance scientific knowledge.

According to Daniel Murphy (1995), the Czech educator John Amos Comenius who was the first to formulate the idea of "education according to nature" that was so influential at the time, had emphasized that science instruction must move from words to things and teach useful knowledge. The balance of subjects, how many are taught and the time allocated to each portion is more important in describing lessons. Good uses of time and positive correlations are noted between instruction time and students' achievement at both primary and secondary levels. Effective teaching activities of schooling are broadly agreed benchmarks of pedagogic and student-centered approaches for better learning that facilitate cooperative learning, development of critical thinking and problem-solving skills needed to build the allround development of children.

In Ethiopia, the primary and secondary schools syllabi promote developmental approaches as they specify the learning outcomes in each subject with a clear learner-centered focus theoretically. The goals of schooling are to give learners feedback and improve learning 
and teaching practices and assessments. Regular, reliable and timely (continuous) assessments are keys to improve learning achievements. Despite the progress in providing education for all as per the motto of universal primary education made so far, education in Ethiopia faces several challenges that constrain its quality, effectiveness, portions coverage, practical knowledge and relevant experiences. As Primary Schools are bases for Secondary Schooling, Secondary Schools play pivotal roles and layout steppingstones for higher institutions.

In educating children, early age barriers, destitution, dropouts and class repetitions are additional obstacles to the incompletion of portions of lessons prescribed in accordance with the given curricula and the time budget, which declines or devastate the educational quality, skill power and promotions throughout the continuing educational and professional development of students. Lack of educational facilities like the conducive-classroom environment, laboratories, equipment, instructional materials and teaching or learning aids are obstacles of the process of teaching and learning.

\section{Statement of the problem}

As a lecturer of biology education and researcher in environmental sciences at Addis Ababa University, while teaching students who joined the undergraduate program of the $\mathrm{x}$ Department of Biology Education, I found out that many students could not achieve required academic results in prescribed biology education courses.

In order to solve the problem, a special readmission class was allowed enabling 36 dismissed students to complete remaining courses and graduate (2010/11). Owing to the reason that the students were incompetent to complete the designated courses as per the given time budget, students were allowed to repeat courses and fulfill basic requirements to gain their first degree. Additionally, many students fail in the Ethiopian grades eight, ten and twelve national examinations and remain as illiterate and jobless citizens that also should depend on someone else or become excellent thieves to live. Hence, such incompetence of many students in the national assessments, the higher institutions were crucial indicators that gesticulated and initiated me to find out or investigate the causes of poor academic background knowledge accumulated in primary and Secondary schools and the reasons of failures throughout the academia and the dismissals of students across Universities.

Among other educational quality failures, omitting prescribed portions or incompletion of the Primary and Secondary Schools were suitably found in all subjects in general and particularly in biology subjects remain as one of the causes or problems of unsuccessful performances of students all the way through the academia or in higher 
education. Issues of omitting portions are the questions of educational wastages that indicate what students have slugged over or uncovered during their early period of schoolings, which need proper reactions and corrective measures promptly. Even if there are many ways of judging the worth and ability of teachers, incompletion of prescribed portions at any level or grade 1 and earners' competencies are the worst of all in the biology didactics.

\section{Purposes of the study}

The general purpose of this study is to identify covered and omitted prescribed portions and find out the valued ranges of taught and slugged over biology portions in grades nine and ten Schools. It also aims at examining the negative impact of omitting prescribed portions on the consecutive academic performances and achievements of students in line with their educational succession in higher institutions and national development.

The specific objective of the study dealt with:

1. Finding out the performances of teaching and learning practicalities, uses of lesson plans, supportive materials in both grades nine and ten biology teaching methods and

2. Investigating the negative impacts on the continuing academic successions of students in higher institutions and answer the following questions.

- Are all grades nine and ten biology portions covered accordingly?

- What are the interactions between lesson plans and teaching practicalities?

- What are the consequences of omitted prescribed portions on the academic succession of students?

\section{Methods and materials}

The study was conducted on the prescribed portions of both grades nine and ten phase-out biology textbooks used before 2010/2011 and the new prescribed portions of phase-in biology textbooks of both grades nine and ten applied since 2011/2012. It was employed in 20 Secondary Schools found in Oromian Regional National State and Addis Ababa city administration of Ethiopia at different times. Ten Secondary Schools of Oromia and Addis Ababa were randomly selected to organize the assessments of prescribed portions coverage of the phase-out biology textbook package, instructional materials, students' exercise books and interviews with teachers and students. For the newly phase-in biology portions coverage assessment, ten Secondary Schools of Addis Ababa City were selected and classroom observation and lesson delivery modes evaluations were evaluated. 
Methodically, empirical data were collected using tools like classroom observations, textbook assessments and interviews and gathered data were enumerated, narrated, processed, described, evaluated and analyzed. Data processing were eventually employed by means of assessments of the coverage of the prescribed portions of both grades nine and ten biology textbooks and practical uses of instructional materials to complete pertinent Secondary Schools learning portions and evaluation of the ability of students to write the national exams set to succeed in the continuing higher learning effectively.

\section{Data collection tools and steps}

Data gathering tools were assessments of coverage of prescribed portions of the textbooks, classroom observations in practical interactions and uses of instructional materials and interviews that were effectively employed as steps listed below.

1. Assessments of the phase-out grades nine and ten biology portions coverage: the phase-out grades nine and ten student textbooks of biology are classified into units that are also arranged into prescribed portions such as theoretical descriptions, activities, determination and experiments (practical works) and projects at the end of each unit. The coverage of each portion was assessed by observing students' exercise books, activities and interviews made with both students and biology teachers.

2. Interviews: in assessment of the phase-out biology textbooks portions coverage, interviews were used to collect information from biology teachers of each school and 5 selected grades nine and ten students.

3. Classroom observations of the phase-in grades nine and ten biology portions coverage: the newly phase-in grades nine and ten students' textbooks of biology compose of prescribed portions such as conceptual explanations, key words of the lesson, pertinent activities, did you know of highlighted terms, review questions, unit summary and end of unit questions in each designated unit. For the purpose of the research, lesson plans designed to cover each portion, lessons delivery methods, supportive materials, evaluation techniques, teaching approaches and all pertinent activities of students in each class were practically observed and professionally evaluated.

\section{Data display}

Data were collected from 20 secondary schools in different times, arranged and constructed into tabular forms in order to present gathered information and manage them in respect to the objectives of the research. Consequently, the following formulated tables consisting of data were displayed with lists of contents and values constructed from collected information. 


\section{Data Analysis}

Data analysis of portions coverage primarily considers preparations of each daily lesson plan, instructional materials and aids and its appropriateness to be specific, measurable, achievable, relevance and time roundedness.

In most cases of classroom observations, lesson plans are designed to complete prescribed portions and submitted to the academic unit of each school only to satisfy the efficiency report and to achieve the portion coverage evaluation points set by the concerned academic units of schools to control the teaching performances and activities of teachers. Teachers usually do not complete prescribed units, portions or even lessons for a single period as per the lesson plan designed; instructional materials are not prepared accordingly due to incompetence of teachers and lack of proper educational management. Despite, the actual completeness or incompleteness of prescribed portions is not reported or tangibly controlled, because, this may cause the loss of evaluation points of quota allotted for portions coverage on teachers and negatively influence pertinent performance evaluation. Lovegrove (1960) cited Rousseau who said that "remember that you must be a man yourself before you try to train a man and you yourself must set patterns he shall copy". It is a true saying that considers the art of teaching as well as the content-knowledge of each teacher to be a teacher.

In observation of students' activities and assessments, assignments are not checked, corrections or feedbacks are not transparently given to the students and most of the time and continuous assessments are not exercised. In data display (Table 1), lists of portions to be covered in both grades nine and ten of the phase-out student textbooks of biology were presented and covered and omitted portions of contents of each unit of textbooks were assessed as per the prescribed curricula.

Table 1. Assessment of the phase-out Secondary Schools biology portions coverage

\begin{tabular}{lllllll}
\hline $\begin{array}{l}\text { Secondary Schools } \\
\text { (Grades 9 and 10) }\end{array}$ & \multicolumn{5}{c}{$\begin{array}{c}\text { Portions coverage assessed } \\
\text { (2008/9-2011/12) }\end{array}$} \\
\cline { 2 - 8 } & Units & Portions & Exercises & Lab works & Teachers & Students \\
\hline BiftuGhimbi & $\mathrm{V}$ & $\mathrm{V}$ & $\mathrm{V}$ & $\mathrm{V}$ & $\mathrm{V}$ & $\mathrm{V}$ \\
Darge & $\mathrm{V}$ & $\mathrm{V}$ & $\mathrm{V}$ & $\mathrm{V}$ & $\mathrm{V}$ & $\mathrm{V}$ \\
DilBer & $\mathrm{V}$ & $\mathrm{V}$ & $\mathrm{V}$ & $\mathrm{V}$ & $\mathrm{V}$ & $\mathrm{V}$ \\
Dilala & $\mathrm{V}$ & $\mathrm{V}$ & $\mathrm{V}$ & $\mathrm{V}$ & $\mathrm{V}$ & $\mathrm{V}$ \\
EntotoAmba & $\mathrm{V}$ & $\mathrm{V}$ & $\mathrm{V}$ & $\mathrm{V}$ & $\mathrm{V}$ & $\mathrm{V}$ \\
Gui & $\mathrm{V}$ & $\mathrm{V}$ & $\mathrm{V}$ & $\mathrm{V}$ & $\mathrm{V}$ & $\mathrm{V}$ \\
Kelemework & $\mathrm{V}$ & $\mathrm{V}$ & $\mathrm{V}$ & $\mathrm{V}$ & $\mathrm{V}$ & $\mathrm{V}$ \\
Kokebe Tsibiha & $\mathrm{V}$ & $\mathrm{V}$ & $\mathrm{V}$ & $\mathrm{V}$ & $\mathrm{V}$ & $\mathrm{V}$ \\
\hline
\end{tabular}




\begin{tabular}{lllllll}
\hline Meskerem II & $v$ & $v$ & $v$ & $v$ & $v$ & $v$ \\
Misrak Goh & $v$ & $v$ & $v$ & $v$ & $v$ & $v$ \\
\hline
\end{tabular}

Accordingly, among prescribed seven units in the phase-out student textbooks of biology designated for grade nine, only five units were touched and the rest portions like activities, experiments and project works of all units remained omitted (untouched) $100 \%$. In few cases, only some of the project works accounting for about $3 \%$ were conducted in the form of group works or homework assignments and also left without corrections and feedbacks. In the same way, the phase-out student textbook of biology designated for grade ten is divided into eight units of which only six units were touched and the last two units were completely ignored. Activities and experimental works were $100 \%$ omitted and few of the project works accounting for $4 \%$ were conducted in the form of group work assignments and commonly left without any checkups and feedbacks. The portions of grade nine and ten (tables 2 and 3), the prescribed portions of each unit of the phase-out student textbooks of biology were evaluated and interpreted into value of ranges with covered and omitted portions and analyzed in terms percentile expressions.

Table 2. Assessment of the phase-in Secondary School biology portions coverage

\begin{tabular}{lcccccc}
\hline $\begin{array}{l}\text { Secondary Schools } \\
\text { (Grades 9 and 10) }\end{array}$ & \multicolumn{4}{c}{$\begin{array}{c}\text { Portion coverage assessments } \\
\text { (2011/12-2013/14) }\end{array}$} & \multicolumn{2}{c}{$\begin{array}{c}\text { Observed classroom } \\
\text { activities }\end{array}$} \\
\cline { 2 - 7 } & Units & Portions & Exercises & Lab works & Teachers' & Students' \\
\hline Belay Zeleke & $\mathrm{V}$ & $\mathrm{V}$ & $\mathrm{V}$ & $\mathrm{V}$ & $\mathrm{V}$ & $\mathrm{V}$ \\
Dilachin & $\mathrm{V}$ & $\mathrm{V}$ & $\mathrm{V}$ & $\mathrm{V}$ & $\mathrm{V}$ & $\mathrm{V}$ \\
Entoto Amba & $\mathrm{V}$ & $\mathrm{V}$ & $\mathrm{V}$ & $\mathrm{V}$ & $\mathrm{V}$ & $\mathrm{V}$ \\
Ft. Abayneh & $\mathrm{V}$ & $\mathrm{V}$ & $\mathrm{V}$ & $\mathrm{V}$ & $\mathrm{V}$ & $\mathrm{V}$ \\
Higher 12 & $\mathrm{V}$ & $\mathrm{V}$ & $\mathrm{V}$ & $\mathrm{V}$ & $\mathrm{V}$ & $\mathrm{V}$ \\
Higher 7 & $\mathrm{V}$ & $\mathrm{V}$ & $\mathrm{V}$ & $\mathrm{V}$ & $\mathrm{V}$ & $\mathrm{V}$ \\
Kelemework & $\mathrm{V}$ & $\mathrm{V}$ & $\mathrm{V}$ & $\mathrm{V}$ & $\mathrm{V}$ & $\mathrm{V}$ \\
KokebeTsibiha & $\mathrm{V}$ & $\mathrm{V}$ & $\mathrm{V}$ & $\mathrm{V}$ & $\mathrm{V}$ & $\mathrm{V}$ \\
Meskerem II & $\mathrm{V}$ & $\mathrm{V}$ & $\mathrm{V}$ & $\mathrm{V}$ & $\mathrm{V}$ & $\mathrm{V}$ \\
Yekatit 66 & $\mathrm{V}$ & $\mathrm{V}$ & $\mathrm{V}$ & $\mathrm{V}$ & $\mathrm{V}$ & $\mathrm{V}$ \\
\hline
\end{tabular}

Table 3. Assessments of the portions coverage of the phase-out biology textbooks

\begin{tabular}{|c|c|c|c|c|c|c|}
\hline \multirow[t]{2}{*}{ Unit portions } & \multicolumn{3}{|c|}{ Grade nine } & \multicolumn{3}{|c|}{ Grade ten } \\
\hline & Total & Omitted & covered & Total & Omitted & Covered \\
\hline Units & 7 & 2 & 5 & 8 & 2 & 6 \\
\hline Activities & 24 & 21 & 0 & 26 & 22 & 0 \\
\hline Experiments & 9 & 9 & 0 & 16 & 16 & 0 \\
\hline Projects & 7 & 7 & 0 & 8 & 8 & 0 \\
\hline
\end{tabular}


Nevertheless, the sum of the value ranges of portions coverage of the grade nine of the phase-out biology textbook in percentile expression accounts for only 33\% whereas the total components accounting for about $67 \%$ of prescribed portions are omitted. In grade ten of the phase-out biology student textbooks prescribed portions coverage, only about $36 \%$ of the valued ranges of the designated portions were covered and the rest $64 \%$ were ignored without any compensation. The total average of both grade nine and ten of the phase-out biology textbooks coverage of all prescribed portions including explanation parts, activities, experiments and project works altogether account for only $34.5 \%$ and the remaining $65.5 \%$ of the prescribed portions of contents of the phase-out biology lessons were left untouched.

Similarly, portions of the newly phase-in grades nine and ten of the student textbooks of biology that compose of portions like explanations, keywords, activities, did you know questions, review questions, unit summary and end of unit questions were assessed (Table 4). All portions of each single unit of both grades nine and ten biology textbooks were assessed and converted into valued ranges of percentile expressions.

Table 4. Values of covered and omitted portions of the phase-out grade 9 \& grade 10 biology

\begin{tabular}{llllll}
\hline Gr & Unit portions & $\begin{array}{l}\text { Value of } \\
\text { ranges }\end{array}$ & $\begin{array}{l}\text { Covered value } \\
\%\end{array}$ & $\begin{array}{l}\text { Omitted } \\
\text { value \% }\end{array}$ & $\begin{array}{l}\text { Coverage } \\
\text { balance \% }\end{array}$ \\
\hline \multirow{4}{*}{9} & Explanation parts & 37 & 30 & 7 & 30 \\
9 & Activities & 23 & 0 & 20 & 0 \\
& Experiments & 20 & 0 & 20 & 0 \\
& Projects & 20 & 3 & 20 & 3 \\
& Total & 100 & 33 & 67 & 33 \\
10 & Explanation parts & 35 & 32 & 3 & 32 \\
10 & Activities & 25 & 4 & 21 & 4 \\
& Experiments & 30 & 0 & 30 & 0 \\
& Projects & 10 & 0 & 20 & 0 \\
\hline & Total & 100 & 36 & 64 & 36 \\
\hline
\end{tabular}

Correspondingly, the phase-in biology textbooks of grades nine portions coverage accounted for only $45 \%$ whereas the rest $55 \%$ of the valued ranges of all portions were omitted. The phase-in biology textbooks of grade ten portions coverage accounted for only $43 \%$ of the valued ranges of portions (Table 5,6) and the rest $57 \%$ of the valued ranges of portions were completely omitted. The grand sum average of value ranges of both grades nine and ten prescribed portions coverage of the phase-in biology textbooks accounted for only $44 \%$ whereas the rest $56 \%$ is omitted untouched.

Table 5. Assessments of portions coverage of the phase-in biology textbooks 


\begin{tabular}{|c|c|c|c|c|c|c|}
\hline \multirow[t]{2}{*}{ Unit portions } & \multicolumn{3}{|c|}{ Grade nine } & \multicolumn{3}{|c|}{ Grade ten } \\
\hline & Total & Omitted & Covered & Total & Omitted & Covered \\
\hline Explanation parts & 6 & 0 & 6 & 5 & 0 & 5 \\
\hline Key words & 108 & 108 & 108 & 70 & 70 & 70 \\
\hline Activities & 67 & 67 & 0 & 60 & 60 & 0 \\
\hline Did you know? & 37 & 37 & 0 & 35 & 35 & 0 \\
\hline Review questions & 17 & 17 & 0 & 31 & 31 & 0 \\
\hline Unit summary & 6 & 6 & 0 & 5 & 5 & 0 \\
\hline End of unit questions & 6 & 6 & 0 & 5 & 5 & 0 \\
\hline
\end{tabular}

Table 6. Values of covered and omitted portions of phase-in grade 9 \& grade 10 Biology

\begin{tabular}{lllll}
\hline Gr & Unit portions & $\begin{array}{l}\text { Value of portion } \\
\text { ranges } \%\end{array}$ & $\begin{array}{l}\text { Omitted portions } \\
\text { value } \%\end{array}$ & $\begin{array}{l}\text { Value of } \\
\text { coverage } \\
\%\end{array}$ \\
\hline $9 \quad$ Explanation parts & 35 & 0 & 35 \\
& Key words & 10 & 0 & 10 \\
& Activities & 20 & 20 & 0 \\
Did you know? & 5 & 5 & 0 \\
Review questions & 10 & 10 & 0 \\
Unit summary & 10 & 10 & 0 \\
End of unit questions & 10 & 10 & 0 \\
Total & 100 & 55 & 45 \\
$10 \quad$ Explanation parts & 33 & 0 & 33 \\
Key words & 10 & 0 & 10 \\
Activities & 22 & 22 & 0 \\
Did you know? & 5 & 5 & 0 \\
Review questions & 10 & 10 & 0 \\
Unit summary & 10 & 10 & 0 \\
End of unit questions & 10 & 10 & 43 \\
\hline Total & 100 & 57 & 0 \\
\hline
\end{tabular}

Interview questions were set for both teachers and students of both grades (considering gender issues) in which females and males participated per school and conducted subsequently. In view of that, about $85 \%$ of teachers of the phase-out biology confirmed that they do not usually complete the prescribed portions accordingly and many portions often remain untouched. Interviewed students of both grades nine and ten also responded that the portions are slugged over and teachers usually do not cover all lesson units and portions prescribed in the student textbooks that directly coincide with students' exercise books observed. They also commented that in both grades, teachers mostly teach theoretically without using teaching aids and omit portions and parts of lessons including designated activities. According to interviewed students and teachers, practical activities designed for identification of substances, determination on sort of matters and experimental works are dully omitted. However, in the newly phase-in biology, teachers confirmed that they complete 
the explanation parts of all units whereas activities and the like portions are again ignored due to reasons like inadequate of time, lack of schooling facilities, instructional materials and conducive environment.

\section{Results}

Based on the study made on the prescribed portions coverage of grades nine and ten of phaseout and phase-in biology textbooks and lesson delivery methods, satisfactory results are investigated.

Most of the lesson presentation activities and teaching styles or lesson delivery modes remain unchanged from the traditional ones or teacher-centeredness that lacks proper lesson plans, teachers' preparedness, instructional and supportive materials, content or subject area knowledge of teachers' and appropriate teaching methodologies. Nonetheless, the following points outshined as a result of the study;

1. The last two units of lessons of both grades nine and ten of the phase-out textbooks portions were not covered,

2. Lessons are mostly taught using teacher-centered approaches irrespective of the lesson plans designed to conduct prescribed daily lessons,

3. In the phase-out biology textbooks of both grades nine and ten biology portions, experiments, activities and projects works are seldom touched,

4. In both grades of the phase-out biology textbooks, the average valued ranges of portions coverage accounted for only $33.5 \%$ whereas $65.5 \%$ of the range value remains untouched,

5. In the phase-in textbooks of both grades nine and ten of biology, activities, did you know questions, review questions, unit summary and end of unit questions portions are ignored,

6. In both grades of the newly phase-in biology textbooks, the average valued ranges of portions coverage accounted for only $44 \%$ whereas $56 \%$ of the value remains ignored.

7. The grand total average of the uncovered or educational wastages of both grades nine and ten of both of the phase-out and phase-in prescribed biology portions of textbooks account for $60.25 \%$ (loss) and only39.75 of the prescribed portions were covered.

8. There is lack of control on lesson planning and portions coverage practically, 
9. Educational wastages or partially or fully incompletion of prescribed portions of subjects including biology throughout Primary and Secondary Schools confidentially determined the academic and professional succession of students by which many of them ended up with academic dismissals from higher Institutions.

10. The result has negatively influenced the consecutive academic performances of students whose consequences ended up with academic dismissals in higher institutions, which is a great barrier to all academic and professional opportunities and national development.

\section{Discussions}

In Ethiopian educational policy, the curricula is set to satisfy the general objective of the country to empower all citizens with adequate literate professional quality targeting the Universal Primary Education, Secondary and Tertiary Trainings as well as the Technical and Vocation Education and Training.

According to Wanna Leka (2001), the purpose of education of Ethiopia is to literate and numerate population that can deal with problems at home and works. She also stated that for many years, Ethiopia made attempts to educate citizens in mass, but achieved little. In view of that, the current situation of uncovering prescribed portions and commonly adopts free promotions or enhancing a child to get promotion without ability, has led to the devastations of educational quality and production of illiterate individuals in which everyone achieves nil.

Dawit Mekonnen (2001) explains that educational and training policy of the country stipulates that curriculum materials should reinforce student-centered instruction and problem solving ability of students. However, in practice, the student-centeredness methods of teaching in general and creating the ability of problem solving in science education in particular is lacking. A teacher assigned to teach a biology lesson in grade nine or elsewhere is expected to think and prepare instructional materials (lesson plans with time budget, teaching aids and other supportive materials) before embarking on teaching and presents lessons in respect to the designed plans in which teaching lesson objectives must be in the three domains knowledge (cognitive), skill (psychomotor) and values (affective).

In teaching, how much and how well students learn and the extent to which their education translates into a range of personal, social and developmental benefits determines the quality. It is the teaching and learning process that brings the curriculum to life that 
determines what happens in the classroom and subsequently the quality of the learning outcomes. In teaching biological sciences, the practitioners, require self-preparations on lab safety rules, effective teaching strategies, observation, pre-hand exercise of the practical experiments, handling tools, equipment operations and report writing before they embark on teaching.

Students come to the classroom somehow with the preconceptions about the world so that the teaching practices must draw out and work with students preexisting understandings and make to develop understanding through in depth learning. Hence, the Meta cognition or thinking about thinking helps students to take control of their learning that create opportunities for students to define learning goals and monitor their own understanding needed to be embedded into classroom tasks.

In teaching biological sciences, students should be given a supportive learning environment based on how to work adherence to all science safety criteria and guidelines for classroom, field and laboratory experiences placing portion coverage at the core of the teaching objectives and activities. Classical experiments confirming well-accepted scientific principles may be necessary to reinforce constructed understandings, teach safe and proper use of laboratory techniques and instruments in biology lessons. In biology for example, the traditional labs such as dissection and observation of plant and animal cells may be quite appropriate that lead to open-ended explorations such as the study of a particular animal's or plant's anatomy in relation to its environment and behavior or the effect of changing environmental conditions on the growth of cells. Usually, techniques of dry experiments are taught at elementary and primary levels whereas the Secondary School is the time when the students are exposed to wet lab experiments by showing yeasts or others cells in practice. Laboratory methods of teaching biology, which is the correct, hectic technique and taking up practical classes, is entirely different from that of the theory so that teachers should have to think how they guide students, take care of the safety and teach the right way to perform experiments that require to conduct special training. The quality of education can be reflected by a meaningful, valuable and responsiveness to individuals and social needs in which each and every student can do without failure and gets those requirements that need understanding of the concept to qualify.

Learning is an integrated, ongoing process occurring within the individual, enabling to meet specific aims, fulfilling needs and interests and coping with the living process. 
Classroom tasks that are worthy of students time and attention, relevant, connected to the world and organized around the big ideas of a subject can develop understanding, intellectual interest and engagement with students.

In Ethiopia, actually, it is a fact that many of schools suffer from an acute shortage of equipment, teaching materials, conducive-learning environment and trained teachers. This is also true from the study conducted that in practical observation, pertinent teachers could not manage lesson delivery practicalities within the time budget as per the designed lesson plan. Incompetence in subject area and content knowledge as well as the professional art lesson delivery techniques are missing across the schools observed. In view of that, across Ethiopia, if we look at the scenario from the teachers' point of view, then we will find responsibilities looming at large that teachers are not well trained to teach effectively or to cope with substance and cover and carry on prescribed portions, particularly activities, demonstrations and experimental works that are so important in teaching biology. Although few teachers try to cover most of the portions, they could not complete all prescribed portions within the given time, i.e. 160 minutes ( 2 hours and 40 minutes) including all activities per week to cover all prescribed biology portions for grade nine or ten.

In teaching processes, instructional language barrier was found as one of the most affecting weak side of teachers wherein some teachers could not introduce themselves and the daily lesson fluently in the language of instruction or English as it must be to the level of pertinent grade. Language of instruction is a policy choice and in all the study schools, students learn in their mother tongue in primary schools (1-8 grades). However, a balance needs to go on enabling students to use local languages in learning and ensuring to have access to global languages. According to Edessa (2014), teaching is the most difficult task that everybody does not fit, whereas some persons have a flair for teaching or the ability to awaken the interest of learners and arrest the attention of students. Effective techniques of teaching or tips of lesson delivery in biology are approaches in which students understand the concepts and the meanings of the lessons and translate into a meaningful practice. In practice, it means establishing a positive classroom environment, ground rules, procedures and consistently reinforcing the teaching to be pleasant, accepting individual differences, gender issues in learning activities, making the class cooperative, supportive and coverage of all prescribed portions.

The art of teaching method includes a series of related and progressive acts performed by the teacher and the students to accomplish the general and specific aims of the lesson. 
Consequently, biology teachers are often ill equipped to foster the development of the skills and dispositions that they so highly value. Biology textbooks and curricula reveal few clues as to how experts organize their biological knowledge, providing few guideposts for novices on their journeys toward expertise. In many respects, textbooks reinforce a scattered and fragmented conceptualization of biology or based on unhelpful organizational schemes such as genetics or plants, which do little to foster effective teaching and transfer practical knowledge. From the stance of effective teaching and research, equipment may be more akin to cognitive resource management and context sensitivity training than supplementing prior knowledge with more and more scientific resources.

\section{Conclusion}

When the prescribed portions are not completed and particularly when practical activities (experimental, demonstration and project works) are seldom touched, it could make the standard of educational quality below the level of requirement and determines the futurity of students. The challenge for teachers is to move inquiry from being a theory or idea to being a disposition that unpins how teachers view their students, subjects and their own teaching practice.

In modern approach, teaching rationality is to bring into conformity with reasoning and creative thinking in biology teaching, which is a practical science. Practical activities in teaching biology are not just motivational and fun, but enable students to apply and extend their knowledge of understanding of biology in novel investigative situations, which can aid learning, memory and stimulate interests. Accordingly, practical biology provides teachers of biology at all levels with experiments that demonstrate a wide range of biological concepts and processes. Experiments are placed within real-life contexts with links to carefully selected further reading, enabling teachers to show relevance and illustrate the key principles of how science works. They promote the sharing of skills and experiences of making experimental works in the classrooms.

Modern teaching methods may incorporate television, radio, computer and other modern devices in order to imprint ideas and concepts into the mind of learners through images and mind mapping. Some educators believe that the use of technology, while facilitating learning to some degree is not a substitute for educational methods that only encourages critical thinking and a desire to learn. Teaching method that focuses on quality 
education allows students to develop and grow in school environments that are supportive and at the same time challenging, which nurture them to become confident, have good self-esteem and willing to strive forward and feel a sense of responsibility towards others in their community. Good methods of teaching makes use of the principles of learning and permits the operation of these principles such as readiness, exercise and effect as provided and utilizes the principle of learning by doing that brings individual differences, stimulates thinking and reasoning, provides growth and development.

In order to summarize gained results and the art of teaching process, the following keynotes listed;

1. Practical activities build up and fix the conceptual understanding,

2. Experiment and project works develop basic skills and prepare the students for higher education,

3. Omitting prescribed portions and values in Secondary Schools affects the academic performances of students in higher education or ignoring particularly the practical activities, experimental and project works upset learners' professional opportunities and end with academic dismissals,

4. Slugging over any portion of the designated Secondary Schools lessons affects the rooting capacity of students in the continuing educational succession so that students who join higher institutions without completing secondary school portions are not ready to attend higher educational courses and mostly end with low marks leading to incompletion of professional training that make them jobless or non-productive citizens and

5. In order to cover prescribed portions and make students successful in all evaluations and professional opportunities, concerned academic units have to devote themselves for the profession and facilitate lesson delivery working conditions in all prescribed curricula and schools.

Overall, many fruitful methods exist for teaching biology and portions coverage if schools are facilitated and equipped and the renovation of pedagogical knowledge is upgrade timely. Continual evaluation of teaching practices with incentives for best teaching works exercised to bring advanced changes in understanding sciences and national development are the soul of teachings. Teaching biology requires consistently focused on innovation, improving the effectiveness and efficiency of teaching and learning, continuity of the forces 
of teaching (resources, technologies and disseminating information), lesson planning, appropriate teaching methods, instructional materials and completion of prescribed portions.

\section{Acknowledgement}

I deeply express my heart-felt thanks to Professor Tesema Ta'a, a senior professor at Addis Ababa University for his invaluable work to revise and advice in writing up this article.

\section{References}

Daniel Murphy (1995). Comenius. A Critical Re-assessment of his Life and Works. Irish Academic Press, UK.

Dawit Mekonnen (2001). The impact of the new primary School Curricula on Teaching practice, role relationship of students and teachers and students' learning behavior: Proceedings of the National Conference on the Quality of Primary Education. Institute of Educational Research, Addis Ababa University, Ethiopia.

Edessa, S. (2014). Biology Subject Area Method II. A module prepared for training Postgraduate Diploma in teaching Secondary School biology. Ministry of Education, Ethiopia.

Lovergrove, N.S. (1960). The Quality of Teaching. A handbook for teachers who intend becoming teachers and for those interested in the education of children. Ministry of Education and Fine arts of Ethiopia.

Ministry of Education (2001). Biology student textbook for grade 9 (phase-out). Reprinted by Mega Publishing Enterprise, Addis Ababa, Ethiopia.

Ministry of education (2000). Biology student's textbook for grade 10 (phase-out). Bole printing Enterprise, Addis Ababa- Ethiopia.

Ministry of Education (2008). Biology student textbook for grade 9 (phase-in). Pearson Education Limited. Edinburgh gate, England in collaboration with Shema Books: Malaysia.

Ministry of Education (2008). Biology student textbook for grade 10 (phase-in). Pearson Education Limited. Edinburgh gate, England in collaboration with Shema Books: Malaysia.

WannaLeka (2001). Primary Education as a Basis for Vocational Technical Education and Training: An issue that deserves attention Proceedings of the National Conference on the Quality of Primary Education. Institute of Educational Research, Addis Ababa University, Ethiopia 